\title{
CORRESPONDENCE
}

\section{Fibroadenoma of ectopic breast tissue in the perianal region}

Sir,

Ectopic breast tissue can be seen along the milk line, which extends from the axilla to the symphysis pubis. The perianal area can be the extreme limit for the presence of such tissue. Ectopic breast behaves like normal breast in its response to hormones and the development of neoplasia ${ }^{1,2}$ and although fibroadenoma and carcinoma can occur, a review of the literature has not identified a previous case of a fibroadenoma arising in ectopic breast tissue in the perianal region.

A 47-year old female presented with a 3-month history of a lump in the left perianal region. It was not tender and had not grown in size. The patient had no bowel symptoms and no significant past medical history. On clinical examination, she had a $3 \times 2 \mathrm{~cm}$, smooth, firm swelling which was anterolateral to the anal margin. Clinically the lump felt like a sebaceous cyst although no punctum was readily visible. The lump was excised under general anaesthesia.

Histologically the mass was a composite tumour composed of ducts and cellular fibroblastic stroma. The ducts had a combined epithelial lining and showed a tendency to cluster into lobule-like formations. The picture was that of a breast fibroadenoma. One small focus of apocrine change was obsenved, and a normal breast lobule was seen outside the periphery of the mass. The tumour was located entirely within the superficial subcutaneous tissue, and no connection with overlying tissues was demonstrated. Most of the covering epithelial layer was keratinized stratified squamous in type without skin appendages, in keeping with the lining of the anal canal. At one margin a junction with adjacent normal epidermis was seen. The lesion was benign and had been completely excised.

The breasts develop as growths of ectoderm about 4-6 weeks of development. ${ }^{3-4}$ The thickened ectoderm forms mammary ridges (or milk lines) extending bilaterally on the ventral surface of the embryo from the base of the hind limb. Failure of regression of this ridge outside the normal position of the breast leads to the development of supernumerary breasts and nipples or ectopic breast tissue. ${ }^{4}$ Ectopic breast tissue in women is localized mainly in the axillary region although other sites are occasionally affected, such as the chest, the abdomen, and anywhere along the embryonic milk line, extending from the axilla to pubis. ${ }^{5-7}$

Areas outside the milk line, such as the dorsal scapular region, have been reported as locations for ectopic breast tissue. ${ }^{8}$ Ectopic tissue can become tender during the menstrual cycle, as normal breasts do, and is subject to the same pathological changes that occur in normally positioned breasts.

De Cholnoky reported fibrocystic changes, mastitis, fibroadenoma and carcinoma in axillary breast tissue. ${ }^{9}$ Others have also reported carcinoma occurring in axillary ectopic breast tissue. ${ }^{6}$ Saleh and Klein reported a case of cystosarcoma phyllodes occurring synchronously in bilateral axillary ectopic breast tissue and others have also found this tumour in ectopic breast tissue. $^{10,11}$ Benign breast epithelium has been reported within axillary lymph node. ${ }^{12,13}$ and although the origin of this heterotopic breast tissue is unknown, Walker and Fectiner speculated that the inclusions are due to incorporation of the breast epithelium during fetal development of these lymph nodes. ${ }^{14}$ Disease has also developed in ectopic breast tissue at other sites, the vulva being the next most common site of ectopic breast tissue. $^{15}$ Adenocarcinoma, intraductal papilloma and fibroadenoma ${ }^{16-18}$ have all been reported in this location. Reeves and Kaufman reported vulvar ectopic breast tissue mimicking a periclitorial abscess. Cohen et al., described a 50-year-old with a sporadic pheochromocytoma, parathyroid adenoma, and ectopic breast with nipple on the dorsal scapular region. ${ }^{19,20}$ Fine needle aspiration cytology has been helpful in diagnosing ectopic breast tissue, ${ }^{21,22}$ but it can provide both false-negative and false-positive results, especially in lactating women. ${ }^{21}$ Excision or incision biopsy may be necessary for definitive diagnosis. If the ectopic breast tissue is symptomatic, complete excision is necessary to prevent recurrence of symptoms and produce an optimal cosmetic result. To the best of our knowledge, this is the first reported case of a fibroadenoma developing in perianal ectopic tissue.

\section{G. Abd El-Monem Siam*} *Associate Specialist Breast Surgeon, Homerton University Hospital 


\section{N. R. Fieldman ${ }^{\dagger}$ \\ ${ }^{\dagger}$ Consultant Surgeon, Newham General Hospital \\ S. J. Diaz-Cano \\ ${ }^{\ddagger}$ Consultant Pathologist, \\ Royal London Hospital \\ M. S. Mahir ${ }^{\S}$ \\ ${ }^{\S}$ Consultant Breast and General Surgeon, Homerton University Hospital \\ Address correspondence to: \\ G. Abd El-Monem Siam, \\ 172 Southend Road, \\ Woodford Green, \\ Essex EG8 8QH, UK}

\section{References}

1. O'Hara M F, Page D L. Adenomas of the breast and ectopic breast under lactation influences. Hum Pathol 1985; 16: 707-712.

2. Foushee J H, Pruitt A B J. Vulvar fibroadenoma from aberrant breast tissue. Obstet Gynecol 1967; 29: 819-823.

3. Johnson C A C, Felson B, Jolles H. Polethelia (supernumerary nipple): an update. South Med J 1986; 79: 1106-1108.

4. Bland K I, Romrell L J: Congenital and acquired disturbances of breast development and growth. The Breast: Comprehensive Management of Benign and Malignant Diseases. Bland K I, Copeland E M III, eds., Philadelphia: WB Saunders Co, 1991, pp 69-86.

5. Haagensen C D. Diseases of the Breast, 2nd edn. Philadelphia: WB Saunders Company, 1971.

6. Saleh H A, Klein L H. Cytosarcoma phyllodes arising synchronously in the right breast and bilateral axillary ectopic breast tissue. Arch Pathol Lab Med 1990: 114; 624-626.

7. Tow S H, Shanmugaratnam K. Supernumerary mammary gland in the vulva. BMJ 1962; 10: 1234-1236.

doi:10.1054/brst.2001.0380, available online at http://www.idealibrary.com on IVEA/

\section{Breast infection with Dirofilaria repens-first reported UK case}

Sir,

We write to describe what we believe to be the first reported UK case of Dirofilaria repens infection affecting the breast.

A 51 year-old woman presented to the breast clinic with a 3-week history of a lump in her left breast. Examination revealed a $1.5 \mathrm{~cm}$, mobile, firm lump in the upper inner quadrant of the left breast, with no axillary lymphadenopathy. Mammography demonstrated a corresponding density. Ultrasound confirmed that this was a well-defined cyst, with "multiple rod-like structures, raising the possibility of a parasitic infection". Fine needle aspiration yielded only copious neutrophils and macrophages, and was unable to confirm or exclude malignancy. In light of the uncertain diagnosis, the lesion was excised under local anaesthetic.
8. Hanson E, Segovia J. Dorsal supernumerary breast. Plast Reconstr Surg 1978; 61: 441-445.

9. De Cholnoky T. Accessory breast tissue in the axilla. NY State J Med 1951; 51: 2245-2248.

10. Andreasen A T. Medullary carcinoma in the axillary breast. Br J Surg 1948; 35: 322-323.

11. Sing J, Sing B, Chander J. Extramammary cystosarcoma phyllodes with bilateral breast involvement. Aust NZ J Surg 1980; 50: 56-58.

12. Edow D W, Carter D. Heterotopic epithelium in axillary lymph nodes: report of a case and review of literature. Am J Clin Pathol 1973; 59: 666-673.

13. Turner D R, Millis R R. Breast tissue inclusions in axillary lymph nodes. Histopathology 1980; 4: 631-636.

14. Walker A N, Fectiner R E. Papillary carcinoma arising from ectopic breast tissue in the axillary lymph node. Diagn Gynecol Obstet 1982; 4: 141-145.

15. Gracia J J, Verkauf B S, Hochberg C J et al. Aberrant breast tissue in the vulva. A case report and review of literature. Obstet Gynecol 1978; 52: 225-228.

16. Hendrix R G, Behrman S A. Adenocarcinoma arising in a supernumerary mammary gland in the vulva. Obstet Gynecol 1956; 8: 238-241.

17. Rickert R R. Intraductal papilloma arising in supernumerary vulvar breast tissue. Obstet Gynecol 1980; 55(suppl): 845-875.

18. Siegler A M, Gordon R. Fibroadenoma in a supernumerary breast of the vulva. Am J Obstet Gynecol 1951; 62: 1219-1224.

19. Reeves K O, Kaufman R H. Vulvar ectopic breast tissue mimicking periclitoral abscess. Am J Obstet Gynecol 1980; 137: 509-511.

20. Cohen N, Modai D, Pik A et al. Coexistence of sporadic multiple endocrine neoplasia and scapular ectopic breast; coincidence or biologically associated? Arch Intern Med 1986; 146 : 1822-1823.

21. Velanovich $\mathrm{V}$. The use of fine needle aspiration in the diagnosis and management of ectopic breast tissue. Am Surg 1995; 61: $277-278$.

22. Bhambhani S, Rajawnshi A, Pant L et al. Fine needle aspiration cytology of supernumerary breasts: report of 3 cases. Acta Cytol 1987; 31: 311-312.

Histology revealed densely fibrotic breast tissue, with marked chronic inflammation and many eosinophils. Necrotic areas within this contained parasitic worms, with morphology consistent with Dirofilaria repens. As these worms lack the capacity to reproduce or to cause systemic disease, ${ }^{1,2}$ the patient was reassured and no further treatment was required.

Filarial infections are common in Africa and the Indian subcontinent, and have been reported in southeastern Europe. ${ }^{1-3}$ The subgroup of Dirofilaria species usually parasitise dogs, but can be transmitted to humans via an insect vector. The larvae give rise to nodules containing immature adult worms. Such subcutaneous lesions can occur in the breast, where they are commonly mistaken for malignancy. ${ }^{3}$ We postulate that our patient acquired the infection during one of several holiday trips to Italy in the mid 1990s. Although parasitic infections of the breast are rare in the West, they should not be forgotten as part of the differential 